This item was submitted to Loughborough's Research Repository by the author.

Items in Figshare are protected by copyright, with all rights reserved, unless otherwise indicated.

\title{
Be prepared for your next 30-second T\&L conversation
}

PLEASE CITE THE PUBLISHED VERSION

http://dx.doi.org/10.21125/inted.2018.0029

\section{PUBLISHER}

(C) IATED

\section{VERSION}

VoR (Version of Record)

\section{PUBLISHER STATEMENT}

This work is made available according to the conditions of the Creative Commons Attribution-NonCommercialNoDerivatives 4.0 International (CC BY-NC-ND 4.0) licence. Full details of this licence are available at: https://creativecommons.org/licenses/by-nc-nd/4.0/

\section{LICENCE}

CC BY-NC-ND 4.0

\section{REPOSITORY RECORD}

Ballesteros-Perez, Pablo, M. Carmen Gonzalez-Cruz, and Daniel Mora-Melia. 2019. "Be Prepared for Your Next 30-second T\&L Conversation". figshare. https://hdl.handle.net/2134/36218. 


\title{
BE PREPARED FOR YOUR NEXT 30-SECOND T\&L CONVERSATION
}

\author{
Pablo Ballesteros-Pérez ${ }^{1}$, M $^{\mathrm{a}}$ Carmen González-Cruz ${ }^{2}$, Daniel Mora-Meliàa \\ ${ }^{1}$ School of Architecture, Building and Civil Engineering, Loughborough University \\ (UNITED KINGDOM) \\ ${ }^{2}$ Departamento de Proyectos de Ingeniería, Universitat Politècnica de València (SPAIN) \\ ${ }^{3}$ Departamento de Ingeniería y Gestión de la Construcción, Universidad de Talca (CHILE)
}

\begin{abstract}
Many relevant bits of our social and professional interactions happen within a few seconds after starting conversations with someone else. Additionally, within the academia, lecturers are frequently exposed to student's complaints or alternative points of view which may challenge the way Teaching and Learning $(T \& L)$ is being managed.

However, students may not speak up when they are asked for feedback, but in out-of-context situations instead. At that moment, the (unprepared) lecturer needs to come up with a good answer. No postponement is allowed and, generally, this lecturer will just have around 30 seconds to go over his/her major points in a clear and comprehensible manner.

This paper reviews the reasons why some innovative teaching methods generally cause some level of discomfort among the students. Examples about the usual complaints that they raise are also analysed. Finally, a series of short dialogues involving both peers and students as locutors and exemplifying how these conversations generally evolve are included.

By means of these short dialogues the reader can better prepare him/herself for key T\&L-related difficult conversations. Anticipating these conversations is relevant because they involve delicate issues about the way the instructor approaches innovative teaching and how the students perceive them. Therefore, this paper provides reflections and additional tools for new lecturers who try to implement T\&L innovations and that have to deal with some opposition among the students.
\end{abstract}

Keywords: student, lecturer, inductive teaching, active learning, cooperative learning.

\section{INTRODUCTION}

Not long ago, in series of talks for professionals and academicians in an International Project Management conference, one of the Keynote speakers brought up an interesting reflection. $\mathrm{He}$ discussed that we are all professionals at some levels, even when we may not be paid for doing some of our jobs. He pointed out that this is probably even truer in the Academic world, where lecturers and professors do teaching, research, grant writing, student work supervision, and also normally take some kind of administrative role without hardly any recognisition for our multi-tasking efforts.

The speaker confessed that, during his career, he had been asked endless times: 'What do you do? or What do you do for a living?' And as many of us do, he usually replied with some worn-out answers which mostly fell in one of these categories: what he had studied, where he was working, what he did on a daily basis and/or which were his latest professional interests.

Apparently, those are easy questions ('What do you do? What do you do for a living?'). We all could probably answer them, and we have probably done it many times. The problem, as the speaker pointed out, are not the questions themselves, but the circumstances in which we normally need to give a reply.

Funnily though, seldom do you receive someone in your office who says: 'Please, could you tell me what you do?' and then he/she sits and gives you as long as we need to go into the nitty-gritty on whatever topic we are working on. Conversely, when answering these questions there is hardly any time to prepare yourself, nor to extend your explanations beyond 30 seconds or a minute before the social interaction ends or the interlocutor's attention drifts off.

Indeed, these short conversations usually happen, for example, when you are getting on a lift with a neighbour ('Hey, how are you? [...] By the way, I didn't know you are working at the university! What do you do there?') or when you are getting home any day from work ('Hi [your name], did you know my son/daughter? He/She is thinking about going to [your university] to study [the school where 
people believe you teach]. Could you tell him/her what you do? He/She is also considering going abroad to study [whatever], maybe you can convince him/her to stay...'). I am sure we all have experienced situations similar like these of some sort.

So, in a way, it is not as much about what we do or what we are, but more about what and how we are able to convey the key points of what we do or what we are to a friend, a relative, a student, or a complete stranger in a matter of seconds. However, the silver lining here is that this phenomenon happens in almost all aspects of our lives and with most of our social interactions, and Teaching and Learning-related situations are not the exception.

\section{TRANSLATION TO TEACHING AND LEARNING (T\&L) SETTINGS}

Generally, it is thought that academicians, unlike many professionals, have a lot of time to sit, reflect, write expert papers, give lectures... that is, to produce well-crafted materials and answers. However, maybe also as a consequence of our continuous interaction with students, many of these interactions with them develop spontaneously and, all of a sudden, they share with you an unexpected piece of information (e.g. a complaint, a bind in which they are in, a divergent point of view concerning what you are doing in class...) and you are supposed to reply in a matter of seconds.

The relevant aspect is that, sometimes, as instructors, we just can excuse ourselves and say: 'I am sorry, but I don't know much about that topic, but I see to it tonight and give you a straight answer tomorrow'. That buffer is available when dealing with technical topics, contents of the course we are teaching or a solution to an exercise that has shown an interesting but unexpected variant.

On the other hand, the type of answers an academician cannot delay have more to do with disagreements, with the way the lecturers handle things, demands about assessments, or the groundbreaking teaching methods we are phasing in and with which our students are not feeling that enthusiastic. To sum up, the students sometimes come up with an unexpected reaction. They just go off and you need to face the situation right on the spot. No answer delay is allowed in these situations, otherwise your credibility might be questioned. And this happens because normally your students will complain about something about which you have already taken an action and either they want to know why, to challenge it, or both.

However, on reflecting on the short time reply windows academicians usually have, it is overwhelmingly evident that the biggest majority of these situations happen to be related to students (not to research, not to co-workers, not to grant management), but to students, and a significant percentage of the issues have to do with the way the students are experiencing/finding/coping with ours or someone else's teaching and/or assessment methods.

Students are, many times, not prone to talk when we want them to. Instead, they will do it anyhow anywhere and anytime when you least expect it. At that moment, you just need to be prepared, because you are just up to five seconds from start talking...

\section{TYPICAL SOURCES OF CONFLICT WITH STUDENTS}

Leaving aside the occasional disagreements with students over a particular piece of assessment or a marking result, many lecturers or instructors may experience a lot of student resistance when they implement one or a combination of these teaching methods in their classrooms:

- Inductive teaching (IT). When a new topic is introduced students, instead of the introductory (theoretically-dense) lecture, they are first confronted with challenges (e.g. questions to be answered, problems to be solved, or observations to be analysed and interpreted) and then they acquire the desired knowledge and skills in the context of addressing those challenges. The most common inductive teaching methods university lecturers use are: inquiry-based learning, case-based instruction, problem-based learning and project-based learning [1, 2]

- Active learning (AL). Many lecturers strongly believe that the only way to master a skill is through practice: trying something, seeing how it works, possibly getting feedback, reflecting on how to do it better, and trying again $[3,4]$. The way to implement $A L$ in the classroom encompasses trying your students to: recall prior material, answer questions, draw diagrams, think of real-world applications, diagnose problems, predict outcomes, sketch solutions, critique findings, brainstorm alternatives, think of new questions and, sometimes, just summarise parts of lectures [5, p.113]. 
- Cooperative learning (CL). $\mathrm{CL}$ is the instruction that involves students working on team assignments with five conditions: positive interdependence, individual accountability, promotive interaction, development and appropriate use of teamwork skills, and regular self-assessment of team functioning [6]. The key is precisely to keep a close eye on the fact that these conditions are actually fulfilled, otherwise the CL experiences might go really wrong [7].

Therefore, despite the effectiveness of these methods is well known both by teaching researchers and practitioners, their first implementations are never easy and problem-free. Indeed, it is from this kind of experiences from which an innovative lecturer may receive a lot of students' opposition. Therefore, of course, those lecturers need to be well prepared to ease their students' concerns. What they might not know is that they may only have 30 seconds to do it.

\section{TYPICAL STUDENTS' QUESTIONS THAT THE LECTURER NEEDS TO BE PREPARED FOR}

Let us imagine a capable university lecturer trying to do his/her teaching job really well. Quite probably, and sooner than later, this person will be implementing IT, AL and/or CL methodologies. It is also likely that our lecturer will gain confidence over time on any of these methodologies as well, but the students will probably find them totally new every year (as the cohorts keep coming).

The consequence is that some students will complain every year. However, if the lecturer is smart, despite the answer time window might only last 30 seconds, he/she might realise that, those questions often fall within a short list of categories. So we'd better teach this lecturer, which may well be you or me, how to master these question answers, because they are going to be recurrent. This is just an excerpt taken from our own experience and from [8]:

* 'I don't take advantage of the group activities. I am paying a lot of money for you to teach me, certainly not to trade ideas with my classmates, who most of the time know much less than $I$ do.'

$>$ Yes, you do pay for me to teach you, but for me teaching is something that happens when you learn something. Do you know that there is a lot of research supporting that people mostly learn by means of practice and by receiving feedback from their peers? [9]. What you are doing in those class activities is the same you will be doing in your homework and eventually in my exams, but you will find out how these run more smoothly once you've been exposed to the class group work.

* 'Yes, but I don't like working in groups anyway, l'd rather do all my homework alone!'

$>$ I am sorry to hear that, but my job here is not to make you happy, but to equip you with the skills you will need once you join the professional world. No company in this world, right after you graduate, is going to ask you whether you prefer to work alone or with someone else. They will just put you in a team, and they will expect you to adapt and work effectively.

* 'OK, but I can't work with my group mates, they are all lazy or stupid! Why can't we choose who we work with? For example, my friends, I know how to work with them.'

$>$ Sorry, again, that is not going to happen. The people you will find in your professional practice are the same that you are working with right now. Some of them will be stupid, some lazy, some procrastinators, some reserved, some more intelligent than you... You'd better learn how to deal with them now, they will be waiting for you in your next company!

With multiple variants, this is just an example of common complaints any good lecturer receives from students. Of course this is not a comprehensive list, it is up to the each academician to raise awareness on these typical questions and learn how to deal with them both quickly and effectively.

However, a lecturer may not receive just different points of view from students concerning his/her innovative teaching methods. Sometimes, the 'attack' can come from a colleague while having a short chat in the building stairs:

* 'Hey [your name], l've heard that you are using 'very innovative' teaching methods this year. What are those methods about? You know, I think the problem is the students not us! Every year they are dumber. If only could the University stop asking us to spend so much time changing the way we teach... They are always trying us to keep following the current teaching 'fashion trends'... We are the ones who know how to teach! Why don't they leave us alone?' 
$>$ You know, it is good that the university cares about improving the quality of our teaching. The problem is that we don't have enough contact hours in the short training sessions they provide us with to learn much more. However, a lot of people teaching here could certainly benefit 'a lot' from learning many things about how to teach more effectively, I mean, apart from the 'oldfashioned lecture' which is what $90 \%$ of what the people here still uses in their classes'

* (Normally with sarcasm) 'Oh, really? and what are those methods for teaching we don't know about? What do you know that we don't?'

$>$ (Here, one can't talk about Intended Learning Outcomes and things like that, but they are too far to understand their importance). Well, what I do is to plan my sessions thinking about what my students are going to be doing at every minute, not what 'l' am going to be doing. The latter will just be the consequence of the former. If they are doing nothing but listening, we have a problem, they will learn very little.

Let me give you an example, do you remember how you learnt to tie your shoes when you were a child? Probably not, but I am sure your parents didn't give you a lecture about tying shoes (with a Power Point) and then they passed you a multiple-option test to know whether you had learnt to tie your shoes. They just gave you very brief instruction and let you practice, trial and error. Then they gave you some feedback and tips, and then one day, you showed them how you were able to tie your shoes. That's the point, give them the opportunity to work themselves. Our students can read a book at home and learn more than listening to me talk. That is what the contact hours are for. What I am doing is not 'innovative', is just common sense!

They might be convinced or not, but the next time this lecturer meets his/her colleagues they will not make fun of his/her approach to T\&L.

\section{CONCLUSIONS}

Many of our social interactions happen within a tight time frame. However, this is not limited to our social life, it also happens in our daily professional interactions.

Within the academia, lecturers and instructors are also exposed to these necessary brief interactions. However, despite the many dimensions of the academic work, most of them tend to be studentrelated.

Particularly, when students that take a course do not agree with how the lecturer or instructor is handling the class dynamics, some of them feel inclined to show that they are discontent. However and also normally, they do not speak up when you ask them for feedback, rather they unexpectedly do speak in an unexpected situation. At that moment, the lecturer needs to come up with a good answer. No postponement is allowed, and generally the lecturer will have just around 30 seconds to go over the major details of his viewpoint.

A series of innovative teaching methods that cause initial discomfort among the students has been reviewed, and some examples about the usual complaints that they might raise have been analysed. Standard answers any lecturer may give to standard student questions have been detailed. Finally, a brief example involving a peer as the other locutor has been included.

Professional situations in which our academic judgement is questioned are frequent. It is necessary to create a solid defence line and learn how to deal with those interactions that attempt to damage our credibility as teachers. Situations like the ones included in this paper have involved students and peers, but it is up to each teaching professional to properly identify them and learn how to effectively address them, but remember, your counterpart will not probably devote longer than 30 seconds of continued attention, so make them count.

\section{ACKNOWLEDGEMENTS}

This research was supported by the CIOB Bowen Jenkins Legacy Research Fund at the University of Reading (H5405400).

\section{REFERENCES}

[1] M.J. Prince \& R.M. Felder, "Inductive teaching and learning methods: Definitions, comparisons and research bases." Journal of Engineering Education, vol. 95, no. 2, pp. 123-138, 2006. 
[2] M.J. Prince \& R.M. Felder, "The many faces of inductive teaching and learning." Journal of college Science Teaching, vol. 36, no. 5, pp. 14-20, 2007.

[3] M.J. Prince, "Does Active Learning Work? A Review of the Research." Journal of Engineering Education, vol. 93, no. 3, pp. 223. 2004.

[4] W.J. McKeachie \& M. Svinicki, "McKeachie's teaching tips: Strategies, research, and theory for college and university teachers" (12th Ed.). Florence, KY: Cengage Learning, 2005.

[5] R.M. Felder \& R. Brent, "Teaching and learning STEM. A practical guide." ( ${ }^{\text {st }}$ ed.) San Francisco, Jossey-Bass, 2016.

[6] D.W. Johnson, R.T. Johnson \& K.A. Smith, "Cooperative Learning: Improving university instruction by basing practice on validated theory." Journal on Excellence in College Teaching, vol. 25, nos. 3\&4, pp. 85-118, 2014.

[7] K.A. Smith, S.D. Sheppard, D.W. Johnson \& R.T. Johnson, "Pedagogies of engagement: Classroom-based practices." Journal of Engineering education, vol. 94, pp. 87-101, 2005.

[8] R.M. Felder, "Sermons for grumpy campers (Random thoughts series)," Chemical Engineering Education, vol. 41, no. 3, pp. 183-184, 2007.

[9] R.M. Felder \& R. Brent, "Navigating the Bumpy Road to Student-centered Instruction," College Teaching, vol. 44, no. 2, pp. 43, 1996. 